\title{
Meeting NPDES Permit Limits for an Effluent-Dependent Stream
}

$$
\text { CONF-981028-- }
$$

by

W. L. Payne

Westinghouse Savannah River Company

Savannah River Site

Aiken, South Carolina 29808

DISTRIBUTION OF THIS DOCUMENT IS UNLMITED.

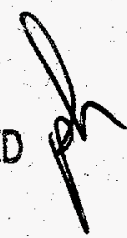

MASTER

A document prepared for WATER ENVIRONMENT FEDERATION (WEF) ANNUAL CONFERENCE at Orlando, FL, USA from 10/3/98 - 10/7/98.

DOE Contract No. DE-AC09-96SR18500

This paper was prepared in connection with work done under the above contract number with the U.S.

Department of Energy. By acceptance of this paper, the publisher and/or recipient acknowledges the U.S. Government's right to retain a nonexclusive, royalty-free license in and to any copyright covering this paper, along with the right to reproduce and to authorize others to reproduce all or part of the copyrighted paper. 


\section{DISCLAIMER}

This report was prepared as an account of work sponsored by an agency of the United States Government. Neither the United States Government nor any agency thereof, nor any of their employees, makes any warranty, express or implied, or assumes any legal liability or responsibility for the accuracy, completeness, or usefulness of any information, apparatus, product, or process disclosed, or represents that its use would not infringe privately owned rights. Reference herein to any specific commercial product, process, or service by trade name, trademark, manufacturer, or otherwise does not necessarily constitute or imply its endorsement, recommendation, or favoring by the United States Government or any agency thereof. The views and opinions of authors expressed herein do not necessarily state or reflect those of the United States Government or any agency thereof.

This report has been reproduced directly from the best available copy.

Available to DOE and DOE contractors from the Office of Scientific and Technical Information, P. O. Box 62, Oak Ridge, TN 37831; prices available from (423) 576-8401.

Available to the public from the National Technical Information Service, U. S. Department of Commerce, 5285 Port Royal Road, Springfield, VA 22161. 


\section{DISCLAIMER}

Portions of this document may be illegible in electronic image products. Images are produced from the best available original document. 
MEETING NPDES PERMIT LIMITS FOR AN EFFLUENT DEPENDENT STREAM

\author{
William L. Payne \\ Westinghouse Savannah River Company \\ Savannah River Site \\ Building 742-A \\ Aiken, SC 29808
}

\begin{abstract}
When the Savannah River Site in Aiken, South Carolina received a National Pollutant Discharge Elimination System permit containing very low copper and toxicity limits for an effluent-dependent stream, an innovative and cost-effective method to meet them was sought. The South Carolina Department of Health and Environmental Control mandated that compliance with the new limits be achieved within three years of the effective date of the permit. SRS personnel studied various regulatory options for complying with the new limits including Water Effect Ratio, use of a Metals Translator, blending with additional effluents, and outfall relocation. Regulatory options were determined to not be feasible because the receiving stream is effluent dependent.
\end{abstract}

Treatment options were studied after it was determined that none of the regulatory pathways were viable. Corrosion inhibitors were evaluated on a full-scale basis with only limited benefits. lon exchange was promising, but not cost effective for a high flow effluent with a very low concentration of copper. A treatment wetlands, not normally given consideration for the removal of metals, proved to be the most cost effective method studied and is currently under construction.

\title{
KEYWORDS
}

NPDES permit, ephemeral stream, effluent-dependent stream, whole effluent toxicity, copper, treatment wetlands

\section{INTRODUCTION}

The South Carolina Department of Health and Environmental Control (SCDHEC) defines ephemeral stream as a stream that flows only in direct response to rainfall or snowmelt and in which discrete periods of flow persist no more than 29 consecutive days per event; however, they have no regulatory definition for a stream that is comprised predominately of flow from a point-source discharge. The proposed amendments to the Clean Water Act in 1995 (HR 961) suggested a definition for effluent-dependent stream (EDS) as follows: The term 'effluent-dependent stream' means a stream or a segment thereof (A) with respect to which the flow (based on the annual average expected flow, determined by calculating the average mode over a 10year period) is primarily attributable to the discharge of treated wastewater; (B) that, in the absence of a discharge of treated wastewater and other primary anthropogenic 
surface or subsurface flows, would be an ephemeral stream; or (C) that is an effluentdependent stream under applicable State water quality standards. SCDHEC uses 7Q10 (the minimum seven day average flow rate that occurs with an average frequency of once in ten years) when deriving National Pollutant Discharge Elimination System (NPDES) permit limits that are based upon water quality criteria. In an EDS, the $7 Q 10$ is often at or near zero. SCDHEC also applies whole effluent toxicity (WET) limits in the NPDES permits they issue to ensure that effluents are not toxic to indigenous animal life. WET is determined by performing a laboratory analysis which measures the aggregate toxic affect of an effluent.

Copper from service water pipe corrosion is the primary toxic pollutant present in one Savannah River Site (SRS) effluent that discharges into an EDS. Lead from pipe corrosion is also present, but not at a concentration significant enough to cause violations of NPDES permit limits. Copper limits of twenty-two micrograms per liter (ug/1) average and thirty ug/l maximum and a "pass/fail" whole effluent toxicity limit are outside of what is routinely achievable for this effluent. The permit limits were established using the United States Environmental Protection Agency (EPA) dissolved metals criteria; nevertheless, the copper limit is well below what is typical in most NPDES permits and is directly attributable to the fact that the receiving stream is effluent-dependent.

\section{Impacts on the EDS}

Studies have shown that the SRS effluent is toxic at concentrations well below the volume used in a WET test. In fact, an effluent concentration of just three percent is chronically toxic to Ceriodaphnia dubia, a water flea typically used in the WET test. A biological analysis of the ditch immediately below the effluent monitoring point indicated that macroinvertebrates, such as damselfly larvae, may be negatively impacted; however, after flowing several hundred yards further down the EDS and passing through a small ponded area created by the construction of a dirt road many years ago, WET analyses indicate that the effluent is no longer toxic. Natural conditions in the EDS effectively lower the copper to non-toxic concentrations.

\section{Options Considered}

SRS considered several regulatory options for meeting NPDES permit limits or having them raised, such as:

- development of a Water-effect Ratio (WER)

- development of a site-specific limit using a metals translator (MT)

- outfall relocation

- blending with other effluents

- determining the background concentration in rainfall

Also considered were several treatment options, including:

- addition of corrosion inhibitor to the process water system 
- construction of an ion exchange treatment system

- construction of a treatment wetlands

\section{REGULATORY NEGOTIATIONS}

SCDHEC established WET limits in the SRS NPDES permit based upon the fact that the effluent is "complex" in nature. It is comprised primarily of noncontact cooling water and cooling tower blowdown, but it also contains the discharges from a large laboratory facility in the area. A careful walkdown by area personnel found that the sole source of copper is from corrosion of non-potable process water piping and not from laboratory discharges. SCDHEC does not consider the source of a pollutant to be an extenuating circumstance unless it is present in the intake water, therefore, SRS personnel were unable to convince them to eliminate or raise the copper limit on this basis.

SRS was given three years to come into compliance with the copper and toxicity limits when a new NPDES permit went into effect on October 1, 1996, Several regulatory options have been evaluated since receipt of the new permit (see Table 1 "Regulatory Options for Meeting NPDES Permit Limits).

\section{Water-effect Ratio}

EPA provided guidance in February, 1994 for the use of a WER in determining NPDES permit limits that are based upon water quality standards. SCDHEC allows permittees to use this methodology when establishing State NPDES permit limits. In order to establish a WER, a permittee must demonstrate that an effluent is less toxic when added to receiving stream water than it is when added to laboratory test water. A ratio between the endpoints of the two tests is established and is used to develop a higher permit limit for a particular toxic pollutant than would normally be calculated using water quality methodology alone.

SRS is unable to take advantage of this option because the effluent consistently fails whole effluent toxicity tests (see Figure 1 "Aquatic Toxicity of SRS Discharge"). In order to take advantage of WER and establish a ratio, an effluent cannot be consistently toxic. The results of these investigations indicate that copper toxicity in the SRS effluent is about the same as it is in laboratory test water.

\section{The Metals Translator}

EPA provided guidance in June, 1996 regarding development of site-specific permit limits based upon calculation of an MT. Use of this option can result in relaxed NPDES permit limits for metals if the concentration of a soluble metal is less than its total concentration in the receiving stream after a mixing zone. MT is not useful for an EDS because the amount of soluble metal in-stream is normally about the same as it is in the effluent. In light of fact that the SRS effluent comprises ninety-nine percent of the EDS, it was pointless for SRS to pursue development of an MT for a site-specific copper limit. 


\section{Point-source Discharge (Outfall) Relocation}

The SRS effluent is comprised of various internal drains and cooling water discharges. The current outfall location was established after a walkdown of the surrounding area by SCDHEC staff. SRS attempted to convince SCDHEC that the proper location of the outfall should be further down the EDS just after a small ponded area, arguing that the EDS was not an ephemeral stream but simply a drainage ditch. In addition, laboratory monitoring at the proposed outfall relocation indicated that the effluent would probably meet discharge limitations for copper and toxicity if pipe corrosion was reduced with corrosion inhibitor (see Figure 2 "Copper Concentration Along the Effluent Dependent Stream"). SCDHEC rejected the alternate location on the basis that the EDS and any associated ponded areas were considered to be "waters of the state" - and waters of the state cannot be used for treatment.

\section{Blending}

Water quality based NPDES permit limits are normally calculated by allowing credit for blending with other effluents and the receiving stream; therefore, the greater the volume blended, the higher the permit limit. For example, the average copper permit limit could have been raised from twenty-two ug/l to forty-three ug/l by either combining it with an additional one-million gallons per day (MGD) effluent source, or discharging it into a different receiving stream with at least a one MGD 7Q10.

Three blending alternatives were evaluated as methods of meeting permit limits. Hard piping the effluent to a receiving stream with a greater $7 Q 10$ approximately four miles away was cost prohibitive. Estimates placed the cost at about four million dollars. Likewise, increasing the number of air strippers used at a groundwater remediation project nearby, and subsequently combining their effluent with the copper laden effluent was considered to be cost prohibitive. Finally, diverting effluent from a different outfall approximately two miles away and combining it with the copper laden effluent was prohibitive due to high capital costs associated with crossing various underground obstructions.

\section{Background Copper Concentration in Rainfall}

The drainage area for the EDS covers several acres and several million gallons of storm water can flow through the outfall during heavy rain events. SCDHEC indicated that they would allow SRS to bypass a treatment system during major rain events if it was shown that outfall limits were being met. In an attempt to avoid having to treat storm water, SRS collected samples after storm water mixed with effluent and measured the copper concentration at various flow rates. The results were disappointing because, as the volume of rain passing through the outfall increased, the concentration of copper also increased (see Figure 3 "Copper Concentration at the Outfall During Rain Events").

SRS continued the rainwater study by analyzing storm water for copper. It was considered possible that copper in the storm water entering the outfall was either 
leaching from the soil as rain passed over it, or was due to the deposition of atmospheric particulates during rain events. Samples of storm water runoff were collected from an area where no industrial activity had occurred. Copper was not detected. Next, samples of rainwater were collected prior to reaching the ground and analyzed for copper. Copper was detected in the first sample, but subsequent samples failed to indicate its presence. This option was not pursued further due to the lack of more definitive data.

\section{TREATMENT OPTIONS}

Since it was clear that effluent limits could not be changed using regulatory options, SRS turned to construction of a wastewater treatment system for meeting very low copper limits. Copper was identified via toxicity identification evaluations as the major cause of toxicity, so a treatment option that could effectively reduce copper to below detectable levels was sought. The effluent concentration was too low to utilize many of the technologies typically used for copper, therefore, only three metals removal methods were given serious consideration.

\section{Corrosion Inhibitor}

Copper in the effluent is attributed to the corrosion of thirty year old piping used to carry non-potable service water throughout the production area. Two corrosion inhibitors were evaluated for addition to the service water to prevent pipe corrosion and reduce the copper concentration in the outfall. One inhibitor, which was a blend of amines, aggravated the problem when tested in a small scale unit. Corrosion of the copper "coupon" in the test apparatus was greater than it would have been under normal conditions. The reason for this phenomenon was not determined.

A second inhibitor containing a triazole compound reduced copper corrosion in the test apparatus, so a full-scale study was undertaken to determine the impact at the outfall. Inhibitor was fed into the process water system and the pH was held above 8.3 standard units. Samples were collected at the outfall and analyzed for copper and WET. The copper concentration in the effluent was reduced by the addition of this corrosion inhibitor, but not enough to consistently meet permit limits. In addition, it did not eliminate aquatic toxicity in the effluent. Corrosion inhibitor was eliminated as a standalone treatment option for these reasons.

\section{Ion Exchange (IE)}

IE is well established as a technology for removal of heavy metals from wastewater. Bench-scale testing on the SRS effluent using various IE resins indicate that excellent copper removal can occur using this form of treatment. But capital costs are estimated to be high and operation and maintenance costs are prohibitive. Frequent regeneration of the IE resin is manpower intensive, and secondary waste disposal is expensive. IE was eliminated as a treatment option for these reasons. 


\section{Constructed Wetlands}

Constructed wetlands are often used for polishing biochemical oxygen demand and nutrients from wastewater effluents; however, wetlands are not very well established as a technology for removing heavy metals. A preliminary evaluation by SRS indicate that a treatment wetlands may be cost effective for removal of copper and toxicity. Kadlec and Knight report copper removal of as much as eighty-eight percent by subsurface flow wetlands. Frostman reports copper removal efficiencies of about ninety percent for mine drainage treated in a subsurface flow wetland containing peat.

A large scale study was undertaken by SRS to evaluate the effectiveness of a subsurface flow wetland at removing copper and other metals. Eight foot diameter tanks (mesocosms) were filled with topsoil and copper laden effluent was routed through them at a hydraulic detention time of approximately twenty-four hours each. The study was conducted for several months and effluent samples were collected and analyzed for copper, lead, zinc and WET. Copper removal was excellent and toxicity was vastly improved by the subsurface flow wetland (see Figure 4 "Effectiveness of Wetland Mesocosm at Removing Copper"). Copper removal averaged around ninety-seven percent and the effluent consistently passed WET testing.

The positive results obtained in the mesocosm test, coupled with relatively low capital, operating and maintenance costs associated with construction of a subsurface flow wetland, convinced SRS to pursue this option for meeting NPDES permit limits. Design of the treatment system is well underway and construction is expected to be complete in time to meet the October 1, 1999 compliance deadline. The total capital cost for the treatment wetlands, including a retention/equalization basin for collection of storm water, is projected to be between three and four million dollars.

\section{DISCUSSION}

The SRS EDS exists only because of the industrial effluents discharging into it. Since the EDS is also ephemeral and considered by SCDHEC to be waters of the state, it must meet the same intended uses required by regulations for fishable and swimmable surface waters - even though these uses will never apply. The fauna that is present in the EDS would not exist if the EDS did not exist. In other words, if the stream was only ephemeral, it would not support even the few species of macroinvertebrates that are currently present. A recent macroinvertebrate study revealed the presence of as many as twelve taxa. This number is clearly below what would be expected in a stream not impacted by toxic pollutants; however, it is greater than what would be present in the stream if it was truely ephemeral and carried only occasional storm water runoff.

SRS evaluated several different regulatory options for meeting effluent limitations for copper and toxicity at the outfall. None of them are viable, either because they are not applicable to streams that are effluent dependent, or the costs to implement them are excessive. Treatment is the only alternative; however, determining a cost effective method of treatment for a high-flow wastewater containing very low concentrations of 
metals is difficult. A subsurface flow constructed wetlands was selected because of its relative low capital cost and its reasonable operation, maintenance, and labor costs.

There are certain risks associated with using a treatment wetland for removing low concentrations of metals from wastewater:

- the technology is not fully established for this purpose

- meeting NPDES permit effluent limitations cannot be guaranteed

- design is difficult

- $\quad$ capital costs are hard to estimate

- seasonal factors are not predictable definitively

These factors notwithstanding, a subsurface flow constructed wetlands is expected to perform well for this application.

\section{CONCLUSIONS}

Clean Water Act implementing regulations are as stringent for Effluent Dependent Streams as they are for other surface waters in South Carolina. A Permittee who discharges into one must have an effluent that is as clean as, or cleaner than, the stream itself. Permittees discharging into an effluent dependent stream with a very low natural flow cannot take advantage of innovative regulatory methodologies established by the Environmental Protection Agency. Instead, costly wastewater treatment facilities must be constructed to protect these normally dry ditches for their "intended uses", such as fishing and swimming - even when such uses will never occur. The Savannah River Site has determined that a subsurface flow treatment wetlands is the most cost effective method for removing low concentrations of copper and meeting effluent limitations.

\section{ACKNOWLEDGEMENTS}

The author wishes to thank Larry Eldridge, Winona Specht, and Eric Nelson for their research and Vernon Osteen for his regulatory expertise - all of which made this publication possible. The support provided by Gary Hoover at the Department of Energy is also appreciated.

\section{REFERENCES}

1. South Carolina Regulation 61-68, Water Classifications and Standards, South Carolina Department of Health and Environmental Control, May 28, 1993.

2. H.R. 961, Clean Water Act amendments of 1995, Section 305 (as amended and passed by the House), May 15, 1995.

3. Interim Guidance on Determination and Use of Water-Effect Ratios for Metals, USEPA, February 1994. 
4. The Metals Translator: Guidance for Calculating a Total Recoverable Permit Limit from a Dissolved Criterion, EPA 823-B-96-007, US-EPA, June 1996.

5.Kadlec, R. H. and R. L. Knight (1995). Treatment Wetlands: Theory and Implementation. Lewis Publishers. Boca Raton, FL., pp. 503-504.

6. Moshiri, G.A., Ph.D. (1993). Constructed Wetlands for Water Quality Improvement. Lewis Publishers, Boca Raton, FL., pp., 198-200. 
Table 1 - Regulatory Options for Meeting NPDES Permit Limits

\begin{tabular}{|c|c|c|}
\hline Option & Description & Invalid Because \\
\hline Water-effect Ratio & $\begin{array}{l}\text { Site-specific permit limit } \\
\text { based upon lab-water to } \\
\text { stream-water toxicity ratio }\end{array}$ & $\begin{array}{l}\text { SRS effluent always fails } \\
\text { whole effluent toxicity tests }\end{array}$ \\
\hline Metals Translator & $\begin{array}{l}\text { Site-specific permit limit } \\
\text { based upon soluble } \\
\text { proportion in receiving } \\
\text { stream }\end{array}$ & $\begin{array}{l}\text { SRS effluent comprises } 99 \% \\
\text { of the receiving stream }\end{array}$ \\
\hline Outfall Relocation & $\begin{array}{l}\text { Move sample location } \\
\text { further down the effluent- } \\
\text { dependent stream }\end{array}$ & $\begin{array}{l}\text { Regulator designates } \\
\text { effluent dependent stream as } \\
\text { "waters of the State" }\end{array}$ \\
\hline Blending & $\begin{array}{l}\text { Route effluent to a different } \\
\text { receiving stream or add flow } \\
\text { from a ground water } \\
\text { remediation project }\end{array}$ & Capital costs too high \\
\hline Rainfall Credit & $\begin{array}{l}\text { Take credit for deposition of } \\
\text { copper in rainfall }\end{array}$ & $\begin{array}{l}\text { Pollutant concentration rises } \\
\text { at outfall during rain events } \\
\text { but copper not present in } \\
\text { rain. }\end{array}$ \\
\hline
\end{tabular}


Figure 1 - Aquatic Toxicity of SRS Discharge

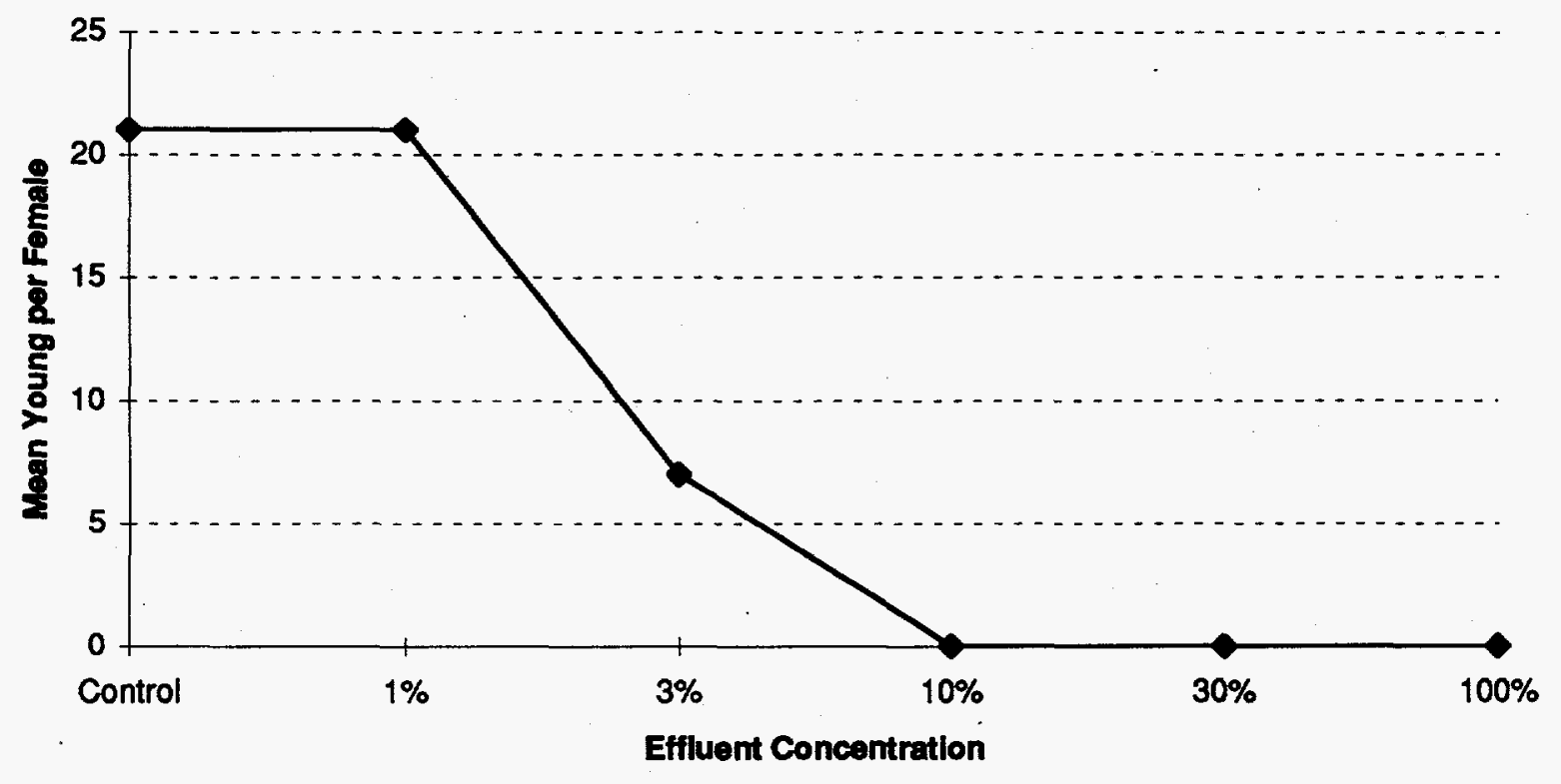


Figure 2 - Copper Concentration Along the Effluent Dependent Stream

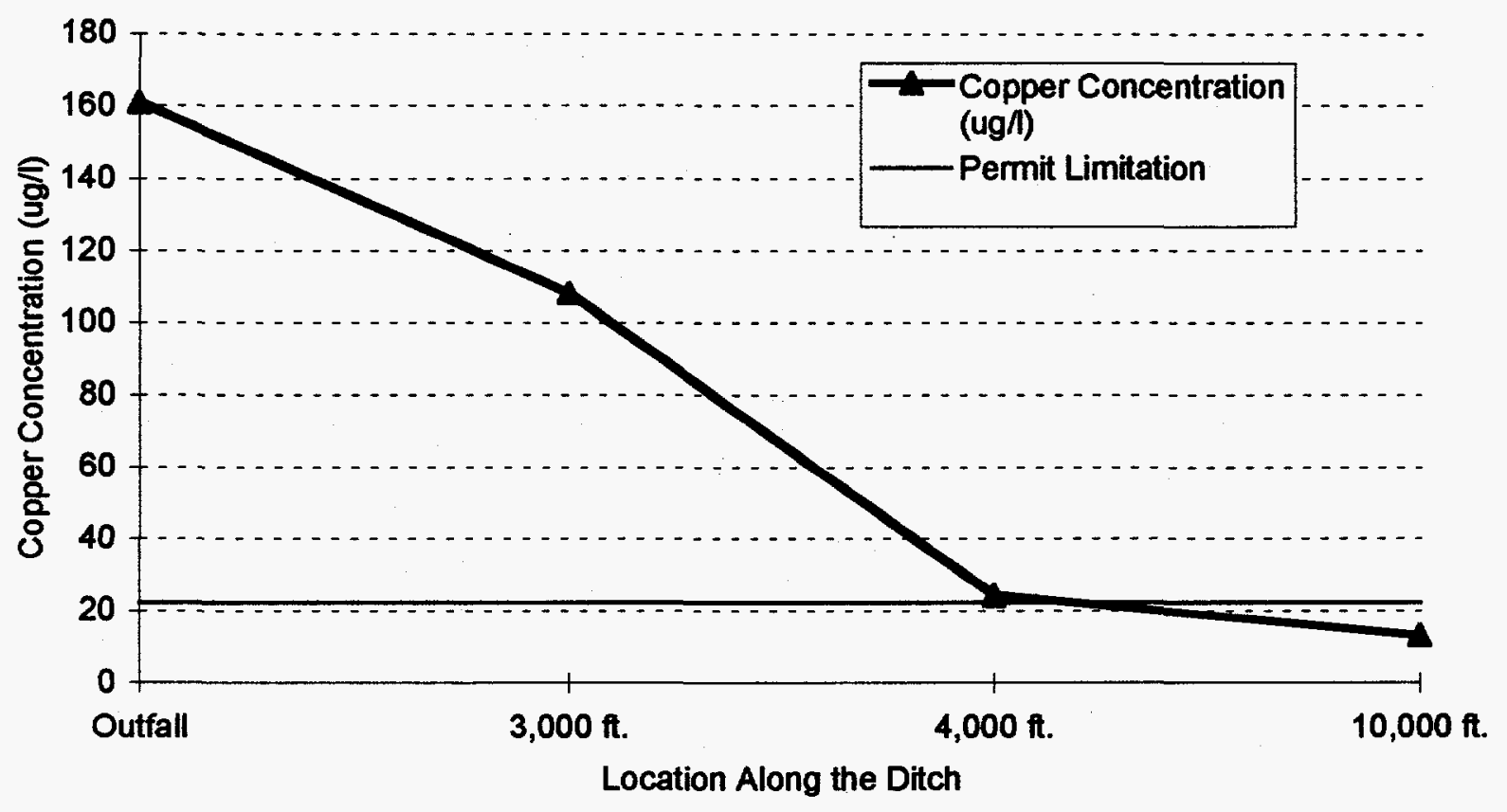


Figure 3 - Copper Concentration at the Outfall During Rain Events

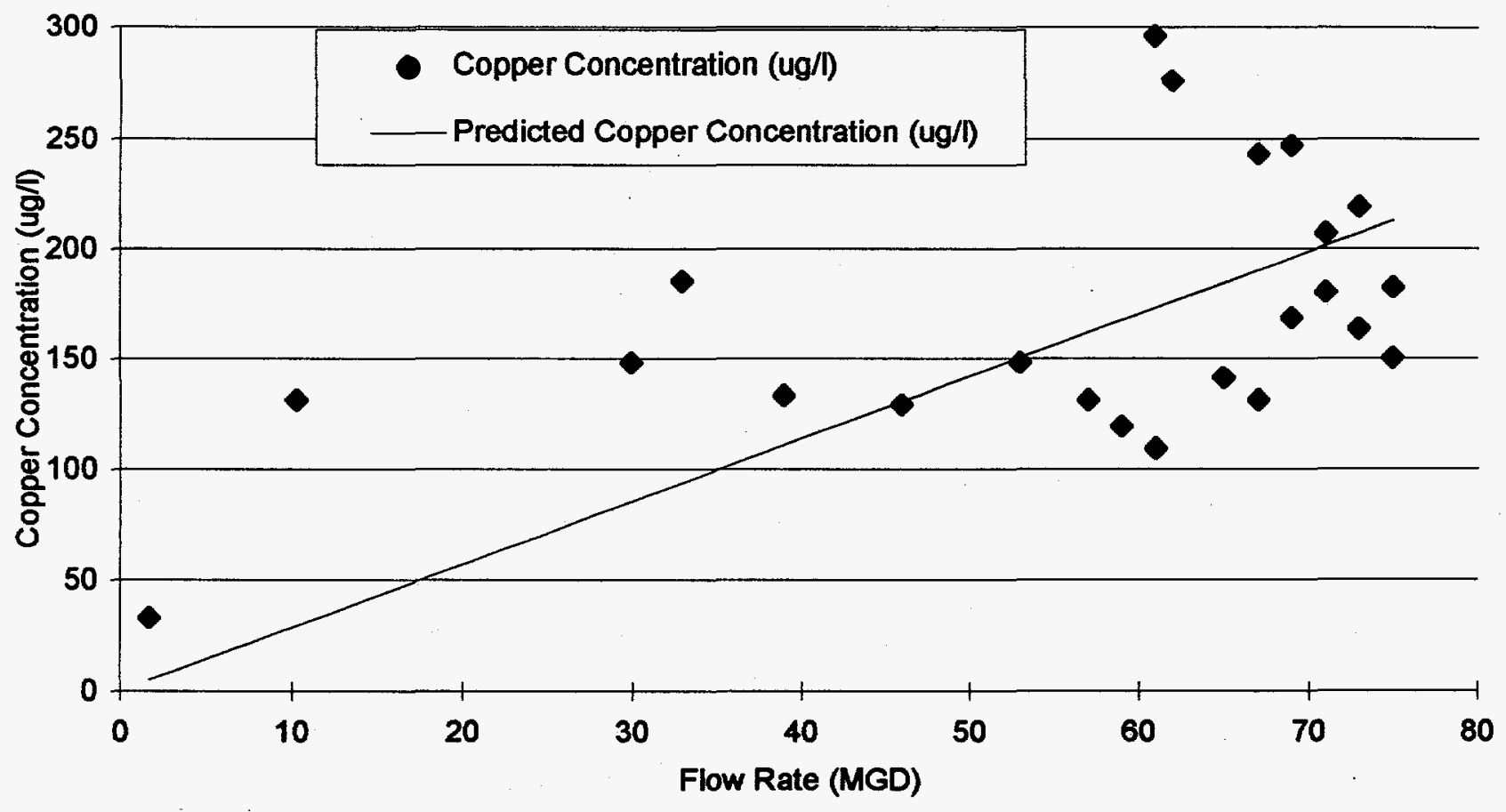


Figure 4 - Effectiveness of Wetland Mesocosm at Removing Copper

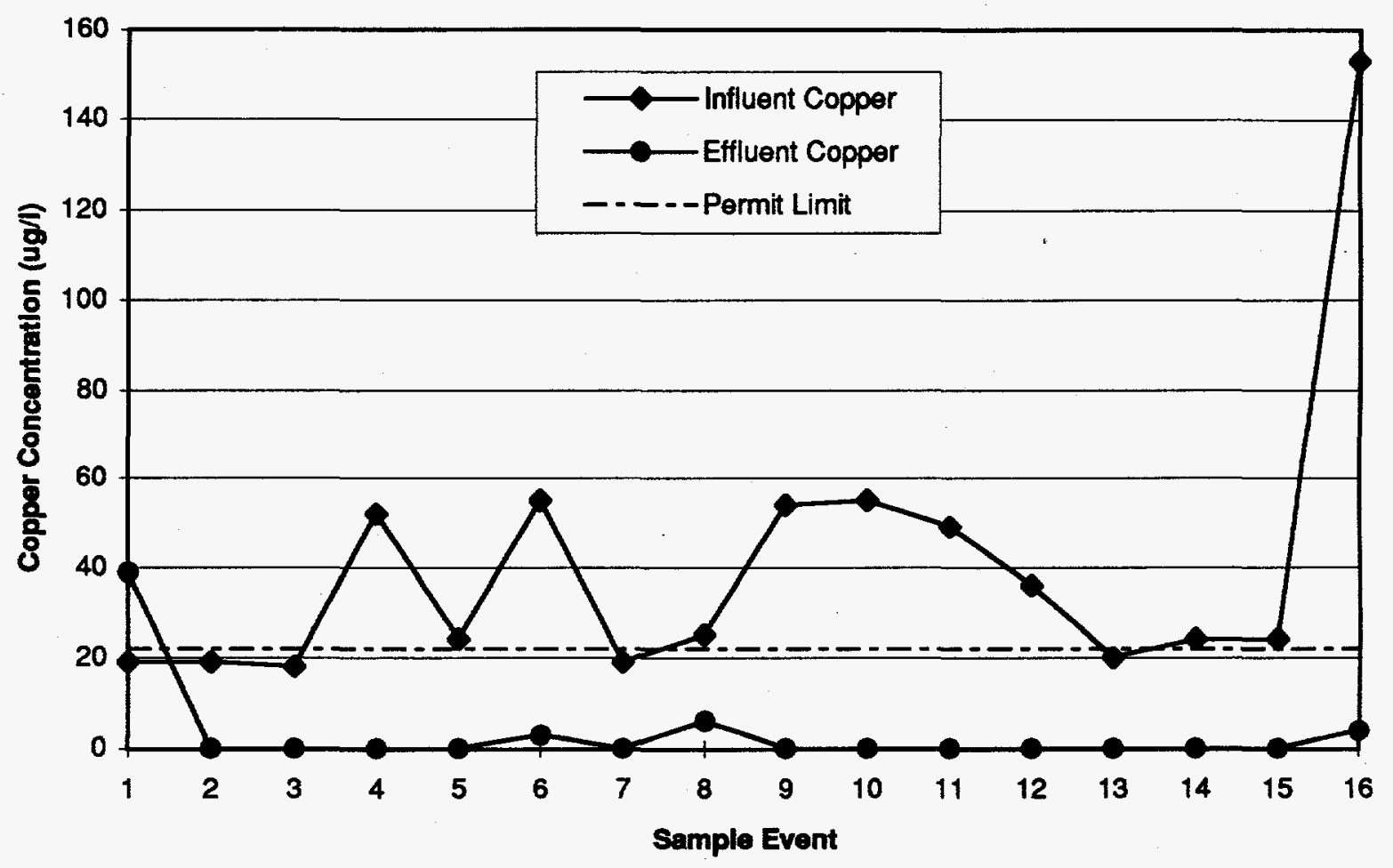

